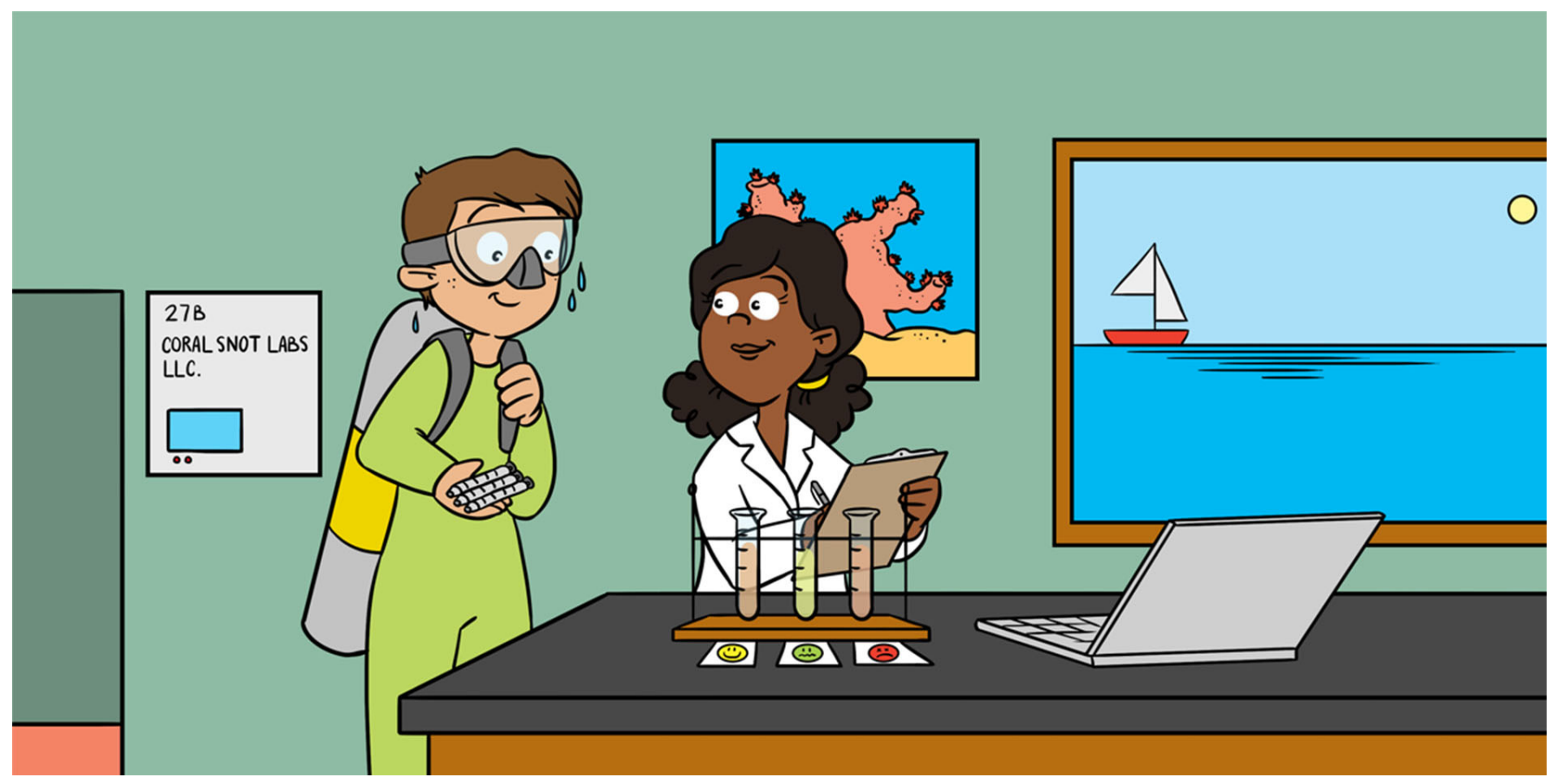

\title{
HOW CAN STUDYING MUCUS PROTECT CORAL REEFS?
}

\section{Jacqueline Rivera-Ortega and Patricia E. Thomé *}

Instituto de Ciencias del Mar y Limnología, Unidad Académica de Sistemas Arrecifales Puerto Morelos, Universidad Nacional Autónoma de México, Mexico City, Mexico

YOUNG REVIEWERS:

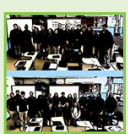

ST. MARY'S

$\mathrm{HIGH}$

SCHOOL

AGE: 14
Corals are an association between animals and plants that deposit a skeleton and build reefs. Coral reefs are now in danger because the marine environment around them is degrading, causing corals to get ill more often. Scientists have used fragments of healthy coral colonies or planted baby corals to help restore reefs that are in bad shape. But for these efforts to succeed, it is vital for the scientists to select healthy corals for planting. Corals use a substance called melanin to trap bacteria that grows in their tissues. We discovered that the enzyme phenoloxidase, which is responsible for making melanin, can be found in the snotty covering of corals, called mucus. We can take samples of this mucus to measure phenoloxidase without harming the corals. By doing so, we can detect whether a coral colony is responding to the presence of harmful bacteria even before it shows any signs of illness. 
Figure 1

Corals are colonies of polyps that are interconnected. Each coral polyp is a small, soft-bodied sac, with a mouth surrounded by tentacles that are used to feed. Each polyp produces and sits on a calcareous skeleton

Corals grow into various forms. The whole colony is covered by a mucus sheet for protection.

\section{POLYPS}

Soft, slimy animals in the shape of a pear, longer than wider. In the apical part are surrounded by tentacles that serves to feed themselves. Individually, are cnidarians known as anemones, but when form colonies, are known as corals.

\section{CALCAREOUS} SKELETON

An external skeleton that corals create and then grow on top of, composed of calcium carbonate $\left(\mathrm{CaCO}_{3}\right)$. Due to this skeleton, corals can build reefs, some of which are so big that they can be seen from space.

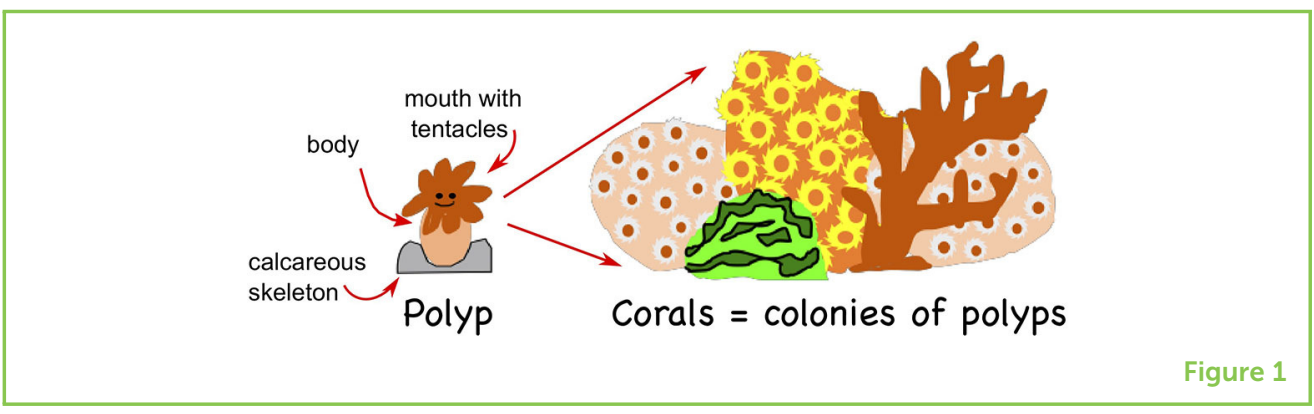

\section{WHAT ARE CORALS?}

Corals are not plants or rocks, but animals that live in tropical seas. Have you ever seen an anemone? Well, the polyps of corals are very similar to tiny anemones. In corals, many polyps group very close together to form a colony, and all those polyps are interconnected. Coral polyps have tentacles surrounding their mouths that help them to feed themselves, by trapping small animals from the surrounding water. The tentacles also help the polyps to eat the bacteria that grow on the surfaces of their bodies (Figure 1). Coral polyps sit on rocks that they make from calcium carbonate, which is called the calcareous skeleton. The calcareous skeleton is composed of calcium (a mineral that gives structure to our bones and teeth), and carbon (the main component of carbon dioxide, a gas that belongs to the greenhouse gases). Corals produce the calcareous skeleton by removing carbon dioxide and calcium from the water.

The calcareous skeletons of corals form big structures, better known as reefs, that house many other marine organisms. Coral reefs also protect the people and communities that are close to the coast, because reefs can reduce the energy that comes from hurricanes by up to $80 \%$. Thus, corals are not just beautiful marine organisms, but they are also very important for other marine species and for human beings.

\section{CORALS CAN GET DISEASES!}

Corals, like every animal on this planet, can get diseases. When corals get sick, the color of their surface changes. For example, corals with black band disease lose some of their surface tissue, leaving a bright white skeleton free of polyps. The main sign of black band disease is the development of a band through the colony, which may be black, red, or brown. There are different kinds of diseases, such as white or yellow band disease or dark spot disease. Once signs of disease are seen in corals, the disease may spread rapidly through colonies, and in time, the whole colony may die. But what can these animals do to protect themselves from getting sick? 
IMMUNE SYSTEM

An organism's system for fighting or resisting the growth or invasion of harmful organisms to prevent disease.

\section{MELANIN}

A substance produced by phenoloxidases. It is responsible for trapping harmful bacteria and other microorganisms.

\section{ENZYMES}

Molecules in the body that help convert one substance into another

\section{PHENOLOXIDASE}

The enzyme responsible for producing melanin. Phenoloxidase is part of the immune system of corals, and when it is being synthesized, other toxic substances are also produced.

\section{CORALS HAVE AN IMMUNE SYSTEM}

Even though corals look like simple animals, they have a complicated immune system. This system has mechanisms capable of healing injuries, killing or engulfing harmful microorganisms, and helping corals to stay healthy [1]. Like humans, corals secrete a snotty layer called mucus that protects and separates their tissues from the surrounding seawater. The mucus layer plays an important role in the immune system of corals. It contains substances that can battle harmful bacteria that might otherwise cause some coral diseases. In humans, mucus works similarly, covering our guts and the insides of our noses and throats. If this mucus layer is breached, our inner tissues, like the coral tissues, can get infected.

Corals also produce a substance called melanin to trap harmful bacteria and other microorganisms. Melanin is made by specific enzymes called phenoloxidases (PO). An increase in the activity of PO can tell us if the coral has started to respond to the presence of bacteria [1]. When PO is being produced, some toxic substances are also produced, which can kill harmful microorganisms. In humans, melanin gives color to our skin. But in corals and anemones (relatives of corals) that have been infected by harmful bacteria, melanin forms darkened clots in their tissues $[2,3]$.

When many corals are damaged or die, the reef loses many of the benefits it provides. In efforts to rescue corals from deteriorating reefs [4], scientists sometimes use fragments of healthy coral colonies or plant baby corals on the damaged reefs. To do this successfully, the scientists must first make sure that the colonies they select to repopulate those reefs are healthy. This is why we decided to take a look into the mucus layer of healthy and sick coral colonies, to see if we could predict whether healthy looking corals were actually healthy or just not showing signs of illness yet.

\section{COLLECTING CORAL MUCUS}

To get a better understanding of the health of coral mucus, we dove down to the reef near our laboratory and, with the help of syringes without needles (one syringe per coral), we carefully sucked up the mucus from the surfaces of healthy and diseased corals. This technique is safe for the corals because it does not damage them at all.

Do you remember how we said that, when corals get diseased, they lose some of their tissues and the diseased areas can be bands or spots with a different color than the healthy coral? Well, when we took the mucus from diseased corals, we collected it from two different parts of the colony: (1) over the damaged tissue (where the coral tissue had changed color) and away from the damaged tissue, over 
Figure 2

Collecting samples of coral mucus. (A) We sampled two kinds of coral colonies: healthy coral Pseudodiploria strigosa and the same species affected by black band disease. (B) We took mucus samples from diseased corals, both over the damaged tissue and over healthy tissue away from the lesion. (C) We collected three samples from five different colonies and analyzed all the samples in the lab for the activity of the PO enzyme.

\section{SPECTROPHOTOMETER}

Laboratory instrument that measures chemical components dissolved in a liquid, by shining a ray of light into the liquid and reporting how much light is absorbed.

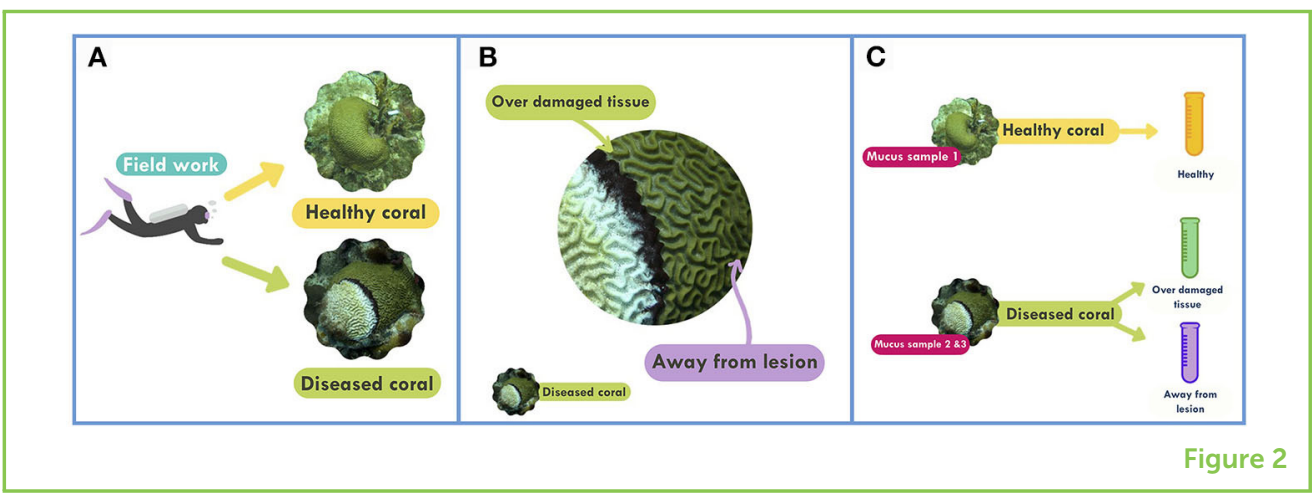

healthy-looking tissue. In healthy corals, we just took mucus from one part of the colony (Figures $2 A, B$ ). Each syringe was labeled so we knew where the mucus came from. Then we took the mucus samples to our laboratory.

Back in the laboratory, we tested the mucus samples by adding substances that stimulated the PO enzyme to make a colored product (Figure 2C). We measured the quantity of the colored product in each sample with a spectrophotometer. A spectrophotometer is an instrument that shines a ray of light through a liquid sample. In our case, the more light the sample absorbs, the more PO activity there is.

\section{WHAT DID WE FIND?}

As we mentioned earlier, coral polyps release immune substances into their mucus. Our first discovery was that the PO activity could be measured in the mucus [5], which is very convenient because, as we mentioned, we can take mucus samples without harming the corals. The second discovery was that there was different PO activity in the mucus samples from healthy and diseased corals. The mucus from healthy corals contained a small amount of PO compared with the mucus from diseased corals. Also, the samples from the diseased corals taken from over the damaged tissue contained the highest quantity of $\mathrm{PO}$, compared with the samples taken further away from the damaged area (Figure 3). Therefore, we discovered that PO activity in mucus is well-correlated with infection: areas with infection have more $\mathrm{PO}$, and therefore more activation of the immune system, than healthy areas.

\section{WHAT CAN WE DO TO HELP CORALS?}

The next step in this research is to determine the normal level of PO activity present in mucus from various healthy coral species. PO activity in the mucus can tell us about the coral's health. Then, when scientists want to collect larvae or fragments from healthy 
Figure 3

$\mathrm{PO}$ activity in the brain coral Pseudodiploria strigosa is affected by black band disease. In this plot, the three bars show the PO activity present in the healthy mucus samples (yellow), and in the mucus samples from diseased corals, taken a distance away from the damaged area (purple), and over damaged tissue (green). The plot shows that the activity of $\mathrm{PO}$ is low in healthy colonies but increases to medium levels in mucus taken from healthy looking areas of diseased colonies and is highest in samples taken over damaged coral tissue.

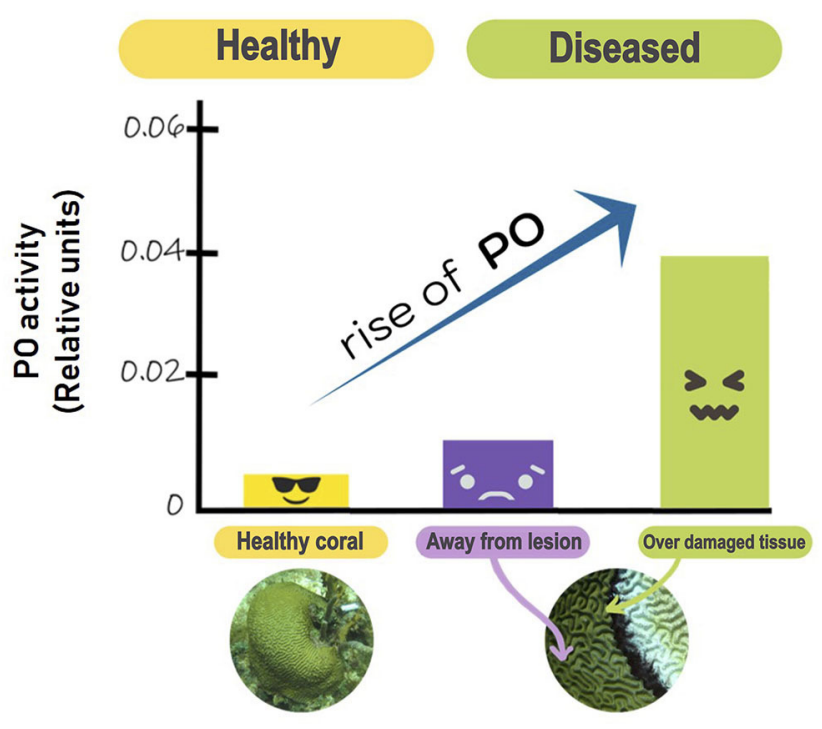

Figure 3

coral colonies to help rescue diseased coral reefs, they can test the apparently healthy colonies first, to make sure they are healthy, before they are used in the rescue efforts. Saving sick coral reefs with healthy coral fragments can contribute to the preservation of this extremely important marine ecosystem.

\section{ORIGINAL SOURCE ARTICLE}

Rivera-Ortega, J., and Thomé, P. E. 2018. Contrasting antibacterial capabilities of the surface mucus layer from three symbiotic cnidarians. Front. Mar. Sci. 5:392. doi: 10.3389/fmars.2018.00392

\section{REFERENCES}

1. Palmer, C. V., Traylor-Knowles, N. G., Willis, B. L., and Bythell, J. C. 2011. Coral uses similar immune cells and wound-healing processes as those of higher organisms. PLOS ONE 6:e23992. doi: 10.1371/journal.pone.0023992

2. Zaragoza, W. J., Krediet, C. J., Meyer, J. L., Canas, G., Ritchie, K. B., and Teplitski, M. 2014. Outcomes of infections of sea anemone Aiptasia pallida with Vibrio spp. pathogenic to corals. Microb. Ecol. 68:388-96. doi: 10.1007/s00248-014-0397-2

3. Palmer, C. V., Mydlarz, L. D., and Willis, B. L. 2008. Evidence of an inflammatory-like response in non-normally pigmented tissues of two scleractinian corals. Proc. R. Soc. 275:2687-93. doi: 10.1098/rspb.2008.0335

4. Liman, D., and Schopmeyer, S. 2016. Ecological solutions to reef degradation: optimizing coral reef restoration in the Caribbean and Western Atlantic. PeerJ 4:e2597. doi: 10.7717/peerj.2597

5. Rivera-Ortega, J., and Thomé, P. E. 2018. Contrasting antibacterial capabilities of the surface mucus layer from three symbiotic cnidarians. Front. Mar. Sci. 5:392. doi: 10.3389/fmars.2018.00392 
SUBMITTED: 17 January 2020; ACCEPTED: 03 September 2020;

PUBLISHED ONLINE: 19 October 2020.

EDITED BY: Dominik K. Großkinsky, Austrian Institute of Technology (AIT), Austria

CITATION: Rivera-Ortega J and Thomé PE (2020) How Can Studying Mucus Protect Coral Reefs? Front. Young Minds 8:527874. doi: 10.3389/frym.2020.527874

CONFLICT OF INTEREST: The authors declare that the research was conducted in the absence of any commercial or financial relationships that could be construed as a potential conflict of interest.

COPYRIGHT () 2020 Rivera-Ortega and Thomé. This is an open-access article distributed under the terms of the Creative Commons Attribution License (CC BY). The use, distribution or reproduction in other forums is permitted, provided the original author(s) and the copyright owner(s) are credited and that the original publication in this journal is cited, in accordance with accepted academic practice. No use, distribution or reproduction is permitted which does not comply with these terms.

\section{YOUNG REVIEWERS}
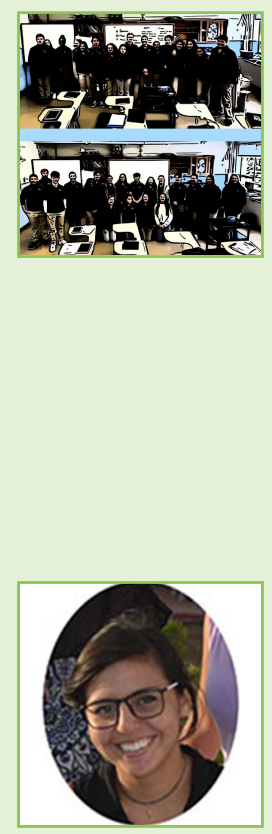

\section{ST. MARY'S HIGH SCHOOL, AGE: 14}

St. Mary's is a Catholic, college-preparatory school developing students in grades 6-12 from more than 30 communities on Boston's North Shore. Shaping authentic men and women of talent and faith. The Honors Biology course focuses on developing scientific inquiry skills that can be applied throughout the students' academic experiences. It has been an incredible experience for our students to get direct experience in the peer-review process and we are so excited to see the final product.

\section{AUTHORS}

\section{JACQUELINE RIVERA-ORTEGA}

I am a passionate coral student. I studied Biology in Mexico City and my master's in marine sciences in Puerto Morelos, Quintana Roo, both at UNAM. During my bachelor, I studied the relation between diseased corals and a river affluent. In my master I decided to go deep and study the coral innate mucosal immunity. I want to continue this amazing research line during my Ph.D.! I am convinced that communicating what we do in science is a good way to ensure that people know what corals are and, if people know corals, they will want to conserve them.

\section{PATRICIA E. THOMÉ}

During my master's studies, I worked with corals. Their beauty and importance captured my immediate interest. I obtained my Ph.D. in Biology at the University of California Santa Barbara. I then moved to UNAM in Puerto Morelos, México, where I have been working as a professor since 1996. My interest in corals has been mainly on the symbiosis they maintain with microscopic algae. I study how different types of 
symbionts benefit corals and other symbiotic animals, like anemones and medusas. I have worked with the immunity of corals recently, concerned by the high incidence of coral diseases. *thome@cmarl.unam.mx 